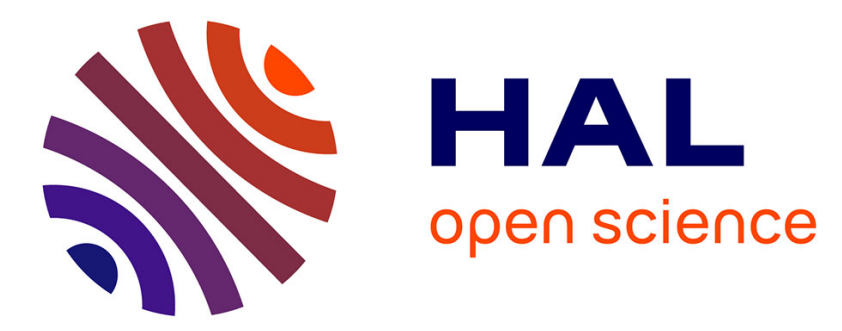

\title{
Landscape perceptions and social representations of Fallopia spp. in France
}

Soraya Rouifed, M. Cottet, M. de Battista, Y-F Le Lay, Florence Piola, P. Rateau, A. Rivière-Honegger

\section{- To cite this version:}

Soraya Rouifed, M. Cottet, M. de Battista, Y-F Le Lay, Florence Piola, et al.. Landscape perceptions and social representations of Fallopia spp. in France. The Science of Nature Naturwissenschaften, 2018, 105 (67), 10.1007/s00114-018-1592-7 . halshs-01972457

\section{HAL Id: halshs-01972457 https://shs.hal.science/halshs-01972457}

Submitted on 10 Jan 2019

HAL is a multi-disciplinary open access archive for the deposit and dissemination of scientific research documents, whether they are published or not. The documents may come from teaching and research institutions in France or abroad, or from public or private research centers.
L'archive ouverte pluridisciplinaire HAL, est destinée au dépôt et à la diffusion de documents scientifiques de niveau recherche, publiés ou non, émanant des établissements d'enseignement et de recherche français ou étrangers, des laboratoires publics ou privés. 


\title{
Landscape perceptions and social representations of Fallopia spp. in France
}

\author{
S. Rouifed ${ }^{1,2}$ (i) $\cdot$ M. Cottet $^{3} \cdot$ M. de Battista ${ }^{4} \cdot$ Y-F Le Lay ${ }^{3} \cdot$ F. Piola ${ }^{1} \cdot$ P. Rateau ${ }^{4} \cdot$ A. Rivière-Honegger ${ }^{3}$
}

\begin{abstract}
Choices have to be made to manage invasive species because eradication often is not possible. Both ecological and social factors have to be considered to improve the efficiency of management plans. We conducted a social study on Fallopia spp., a major invasive plant taxon in Europe, including (1) a survey on the perception of a landscape containing Fallopia spp. using a photoquestionnaire and (2) an analysis of the social representations of Fallopia spp. of managers and users in one highly invaded area and one less invaded area. The respondents to the photoquestionnaire survey appreciated the esthetics of the landscapes less when tall Fallopia spp. were present. Few people were able to identify and name the plant, and this knowledge negatively affected the appreciation of the photos containing Fallopia spp. The central core of the social representation of Fallopia spp. was composed of the invasive status of the plant, its density, and its ecological impacts. The peripheral elements of the representation depended on the people surveyed. The users highlighted the natural aspect whereas the managers identified the need for control. In the invaded area, the managers qualified the species as "unmanageable," whereas the species was qualified as "foreign" in the less invaded area. Those results provide insights that have to be included when objectives of management plans of these species are selected.
\end{abstract}

Keywords Japanese knotweed s.l. · Perceptions $\cdot$ Photoquestionnaire $\cdot$ Ranked associations $\cdot$ Social representations

\section{Introduction}

The production of knowledge on ecosystems and landscapes, particularly in applied research, often needs to integrate both ecology (or more generally, biophysical science) and social science because they are recognized as "social-

Communicated by: Matthias Waltert

Electronic supplementary material The online version of this article (https://doi.org/10.1007/s00114-018-1592-7) contains supplementary material, which is available to authorized users.

$\triangle$ S. Rouifed

srouifed@isara.fr

1 CNRS, ENTPE, UMR5023 LEHNA, Univ Lyon, Université Claude Bernard Lyon 1, F-69622 Villeurbanne, France

2 Present address: ISARA, 23 Rue Jean Baldassini, F-69364 Lyon, France

3 CNRS, UMR 5600 EVS, ENS de Lyon, Université de Lyon, F-69007 Lyon, France

4 CHROME - EA 7352, Unîmes, Université de Nîmes, Nîmes, France ecological systems" that include human and ecological conditions, patterns, and processes that interact with each other (Redman et al. 2004; Ostrom 2009). Interdisciplinary research is a good way to better comprehend complex systems and may reveal surprising outcomes and reciprocal effects (Liu et al. 2001, 2007). Indeed, the management of ecosystems has been proven to be better understood and more efficient when ecological and social factors are considered (Austin et al. 2013; Turner et al. 2016). Social and socioecological studies are still lacking in invasion science, even if some studies emerged from the 1990s and the 2000s, respectively (Vaz et al. 2017).

The various ecological mechanisms involved (Catford et al. 2009) and the ecological impacts (Simberloff et al. 2013) of invasive species are widely studied. The management of widespread and well-established invasive species is difficult and needs to prioritize and optimize control efforts (Epanchin-Niell and Hastings 2010; Giljohann et al. 2011; Hohmann et al. 2013) according to ecological, economic, and social criteria, including perceived benefits and impacts of the species (Gaertner et al. 2017). Moreover, different value systems of stakeholders may even lead to some conflicts about 
appropriate management strategies (Estévez et al. 2015). Consequently, invasion management requires studying and clarifying social dimensions around invasive species (Simberloff et al. 2013; Tassin and Kull 2015), which can be achieved by further considering human perceptions (Andreu et al. 2009) and social representations (Selge and Fischer 2011).

Landscape perception is a process that connects humans with ecological phenomena (Gobster et al. 2007). The perception of esthetics is triggered not only by emotionally based processes but also by cognitively based processes (Gobster et al. 2007). Some components in landscapes can be widely preferred esthetically, whereas other components can be appreciated differently depending on the culture (Le Lay et al. 2008). The perception of landscapes can also be influenced by people's knowledge, such as academic education or different areas of expertise (Wyzga et al. 2009). Professionals have already been demonstrated to perceive non-native plant species as less beautiful than the public perceives them to be (Fischer et al. 2014). There is a relationship between the content of beliefs and the perceptions of people and their attitudes (Fischer et al. 2014) that may not be consistent with the landscapes' ecological functions or conditions (Cottet et al. 2013; Gobster et al. 2007; Wyzga et al. 2009). Studying the perception of esthetics may thus partly explain how people feel about, behave in response to, and act on landscapes.

Social representations are sets of values, information, and ideas that are shared by a social group about a given phenomenon or object (Moscovici 1961). From the point of view of social representation theory, the outside and inside worlds of individuals and groups are not separate. The subject and object are not fundamentally distinct concepts (Moscovici 1989). Social representations provide group members with a common reference point that enables them to understand and explain reality. Given their functional (Abric 1994a; Rouquette and Rateau 1998), evaluative (Rateau 2002) and normative (Flament 1999) components, social representations guide behaviors by providing direction and adjusting them to the sociocultural context. Given the relationship between social representations and uses (such as Zouhri et al. 2016), they can consider the complex mechanisms involved in positioning oneself regarding a specific social object. Hence, social representations are appropriate for studying environmental issues because they focus both on socially constructed and cognitive (internal) aspects, and thus can clarify the complexity of people's views about their natural environment (Buijs et al. 2012; Figari and Skogen 2011). For example, social representations of nature and landscapes may differ between laypeople and experts, leading to diverging attitudes about management or conservation measures (Buijs and Elands 2013). Indeed, given their roles in understanding and co-constructing reality, we know that social representations play a fundamental role in the way people construct and share their perceptions of problematic objects (here, an invasive species) and behave and interact regarding that object (Abric 1994a; Guimelli 1994).

Japanese knotweed s.s. Fallopia japonica (Houtt.) Ronse Decraene, Giant knotweed Fallopia sachalinensis (F. Schmidt ex Maxim.) Ronse Decraene, and the hybrid between these two species, Bohemian knotweed Fallopia $\times$ bohemica (Chrtek and Chrtkova), are widespread invasive species in Europe (Bailey and Wisskirchen 2004). Fallopia spp. are rhizomatous perennial herbaceous plants that have colonized riparian habitats and disturbed areas (Bailey et al. 2009). The three species are considered invasive but the hybrid seems to perform better than the parent species (Parepa et al. 2014). Numerous control methods have been tested in the field, but none have demonstrated full efficiency (Delbart et al. 2012). Ineffective control actions may even promote propagation (Delbart et al. 2012; Meier et al. 2014), and there is no consensus if the species should be controlled (Delbart et al. 2012). Moreover, little is known about the response of the different taxa to the various control methods. Many stakeholders are concerned, either because they are charged with managing the invaded sites (practitioners) or because they are in contact with the species in different activities or on their properties (laypeople and residents). To date, few studies have collected data on the perceptions and representations associated with Fallopia spp. Robinson et al. (2017) have shown that the perceived frequency and severity of consequences of Fallopia spp. in domestic gardens could depend on direct professional or domestic experience and geographical proximity to Fallopia (knowledge of an invaded site within $5 \mathrm{~km}$ ). Another recent study that analyzed written documents produced by environmental managers in France revealed two main approaches. While some managers focused on the general knowledge related to the origins and strategies of colonization, others emphasized the diversity and efficacy of prospective management techniques (Cottet et al. 2015).

Our aim was to further explore the human-Fallopia spp. link in some hydrosystems in France, both in response to laypeople and managers and in relation to ecological data. We were interested in understanding why and how to adequately manage the species. The complexity of this question makes it very important to study both the biology/ecology of the species and the social attitudes towards the plant. Here, we present two studies focusing on perceptions and representations of the species:

(1) A survey aiming to assess the effects of the presence and height of Fallopia spp. on laypeople's landscape perception,

(2) A structural analysis of the social representations of Fallopia spp. among managers and users of invaded sites from two regions: the Rhône department (highly invaded) and the Gard department (less invaded). 


\section{Methods}

\section{Effect of the presence of Fallopia spp. on the landscape perception of laypeople}

To better understand how individuals perceive landscapes invaded by Fallopia spp., we conducted a photoquestionnaire (Le Lay et al. 2012). A set of photographs was presented to laypeople, who were asked to evaluate the landscapes' esthetics. A few questions followed the photographs to better qualify the sociocultural profiles of the individuals and to assess if they could identify Fallopia.

The photographs were taken along the Rhône River. They were selected and classified according to two criteria: vegetation layer in the landscape (with trees versus with shrubs) and presence and height of Fallopia spp. (without Fallopia/with low Fallopia/with high Fallopia). There were two photographs per set of criteria (12 photographs total, Fig. 1). Since it is known that anthropogenic components (e.g., factories and roads) strongly influence photograph assessments (Real et al. 2000), they were artificially removed using Photoshop software (CS5.1) if present.

The survey was conducted by one investigator in the municipality of Vernaison (Rhône department). Respondents to the survey were selected according to a representative sampling based on an age criterion (INSEE database). The investigator proceeded with the initial contact and the questionnaire administration according to two successive approaches: first, a door-to-door approach; then, to complete the sample, he administered some questionnaires at the municipal library. A total of 136 individuals answered the questionnaire. The age distribution within the sample of respondents was similar to the age distribution in the municipality of Vernaison (Table 1); the gender distribution was more unbalanced since women were overrepresented in our sample in comparison to the population of the municipality (INSEE, census 2013; Table 1). First, the respondents were asked to use an analogous visual scale to rate the esthetics of the landscapes (used for studying landscape perception, such as in Cottet et al. 2013 and Wyzga et al. 2009; Supporting Information Fig. 1). The scale was bounded by assessment terms ("not beautiful at all" versus "very beautiful"). The participants were asked to rate the beauty of each landscape by marking a cross on the scale. This mark was then converted into a rating (from zero to ten) that was used for statistical analyses. Second, a few questions were asked of the respondents to assess their knowledge of Fallopia. They were first asked to name the plant species that they were able to recognize in the photographs. For statistical analyses, the spontaneous naming of Fallopia spp. (or its French vernacular names) versus no naming of Fallopia was used. Then, if the plant was not recognized, the investigator showed photographs of the plant-first without flowers and second with flowers-and asked if the respondent had ever seen it and could name it.

Regarding the esthetic assessment of the landscapes, the differences of the ratings according to the presence and height of Fallopia spp. in the landscape, the knowledge of the surveyed people, and the interaction between both factors were analyzed with analysis of variance (ANOVA) in conjunction with Tukey HSD tests. Statistical analyses and graphs were performed with R software (R Core Team 2012).

\section{Social representations of Fallopia spp. in managers and users}

The study of social representations requires both identifying their content (information, beliefs, and attitudes towards the object) and their organizational structure (Rateau 1999). The central core theory (Abric 1976, 1994a) states that this structure is regulated by two distinct entities with complementary roles. The central system unifies and stabilizes the representation, and thus determines its organization and meaning. It is composed of consensual, non-negotiable, and stable cognitions that are unconditionally linked to the object. It acts as a cognitive filter through which social reality is perceived and evaluated. By providing a "framework for interpreting and categorizing new information," the central system also contributes to determining attitudes and behaviors (Abric 1994b). The peripheral system also consists of conditional cognitions that enable individual variations of the common reference point as defined by the elements of the central system. The peripheral elements are the most concrete part of the representation and act as a "buffer" between the central core and any environmental variations faced by the individual (Flament 1989). Thus, they act as a regulator of the social representation by adapting it to the context, and as a protector and defender of the central core. The peripheral system can also intervene in the determination of social judgements and practices in accordance with the central system. Analyzing the complementarities between the central core and the peripheral system thus provides a better understanding of the structure, content, and dynamics of a social representation.

We adopted this structural approach in this study. We conducted a survey in two different regions of France $(N=94)$. The first region (Vernaison, Rhône basin in the Rhône department) is highly invaded by Fallopia, whereas the second region (in the Vidourle basin, in the Gard department) is less invaded. We surveyed two groups in both areas: managers (technical and scientific agents working on river and riverbanks, 17 in the Rhône and 20 in the Gard) and users (fishermen and residents, 30 in the Rhône and 27 in the Gard).

The sample included a majority of male subjects (20 females and 74 males). However, the ratio of male to female subjects was the same, regardless of the study site $\left(\chi^{2}(3)=\right.$ 1.95 , NS). Furthermore, males and females were equally 
Fig. 1 Photographs used for the photoquestionnaire. Photographs were taken along the Rhône River; any anthropic elements were removed

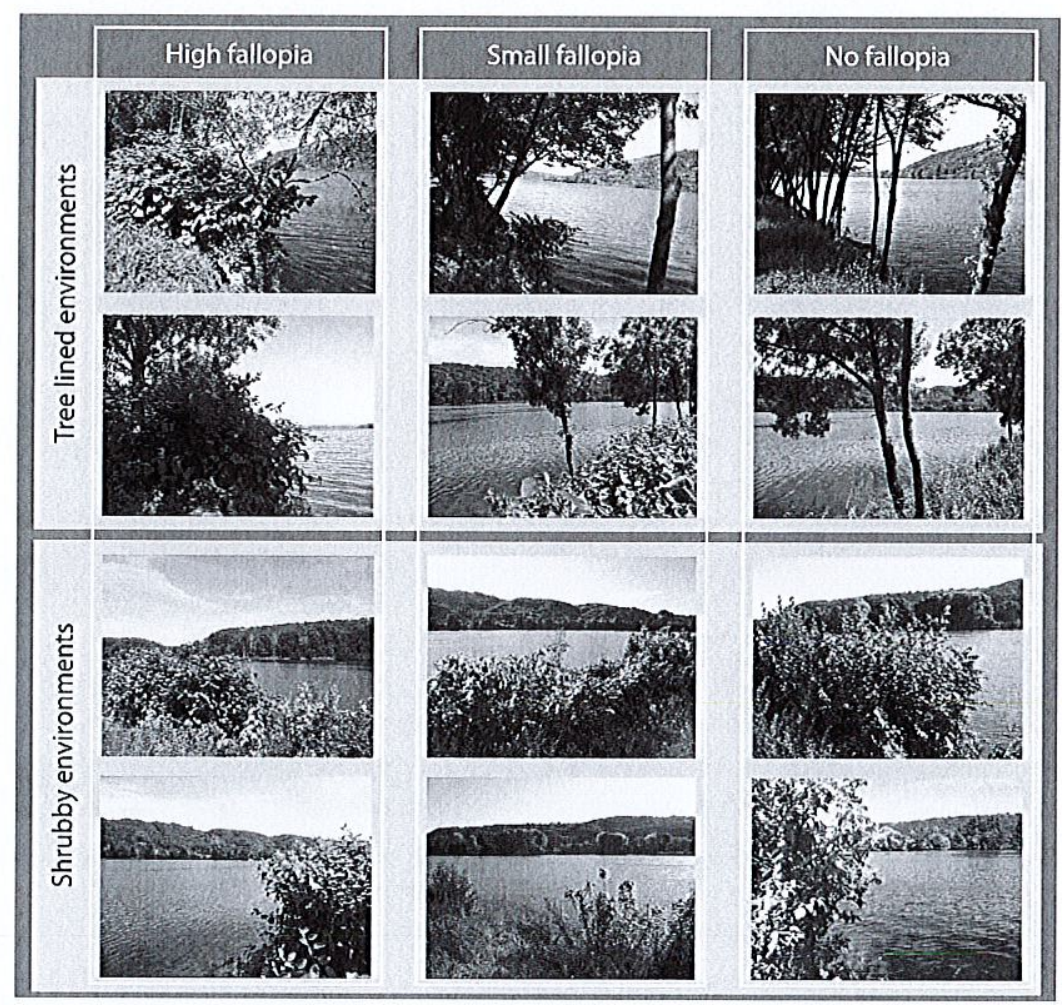

distributed between the five age categories that composed each sample $\left(\chi^{2}(9)=3.95\right.$, NS).

The participants were asked to answer a questionnaire (Supporting Information Fig. 2) used to analyze the structure and content of the social representation of Fallopia spp. We used two methods to analyze the structure and content of the social representation of Fallopia spp.: a prototypical analysis (Vergès 1992) using ranked associations (Abric 2003; Moliner et al. 2002) and a context independence test (CIT; Lo Monaco et al. 2008). The first method requires the participants to cite the first five words or expressions that spontaneously come to mind when they think about Fallopia spp. They were then asked to rank these verbal associations according to their importance in defining Fallopia, from one (the most characteristic of Fallopia) to five (the least characteristic of Fallopia). Using this method, two criteria can be combined to determine the representation's structure: the frequency and the mean rank of each word or expression. In other words, frequently used and high ranked (i.e., important, with a rank closer to 1) elements are considered a potential central element (Vergès 1992). The CIT was used to confirm the potential representational structure identified using the first method. The participants were asked to indicate whether each potentially central element is an unconditional characteristic of Fallopia spp. The participants who answered "yes" judged that the element was always linked to the object of representation. Given the consensual and contextually independent nature of the central elements, a high frequency of affirmative answers indicates that the element in question is central.

Following the initial content analysis by lemmatization (i.e., grouping words or expressions of the same lexical family into semantic elements) of the ranked associations and the intersection of the mean frequency and mean rank of each word, we verified the centrality of each element by comparing the CIT answers to a threshold determined by a Kolmogorov-Smimov test. To identify the organizing factors of the representation according to each population's characteristics, we also conducted a correspondence factorial analysis (CFA) on the 14 semantic elements by defining the location and the two categories of individuals (managers versus users) as the supplementary variables.

\section{Results}

\section{Effect of the presence of Fallopia spp. on the landscape perception of laypeople}

The surveyed population (Table 1) was predominantly female and more than 45 years old. Most participants were familiar or very familiar with the study area since $44 \%$ of them had lived in the municipality for more than 16 years and $41 \%$ had lived there between 6 and 15 years. Regarding their knowledge of Fallopia, only 8 respondents out of 136 were able to name the plant $(6 \%)$. This recognition was equivalent whether we 
Table 1 Characterization of the sample population surveyed with the photoquestionnaire

\begin{tabular}{lll}
\hline Question & Possible answers & Number \\
\hline Age & Between 15 and 29 & 25 \\
& Between 30 and 44 & 42 \\
& Between 45 and 59 & 38 \\
& Between 60 and 74 & 22 \\
& More than 75 & 9 \\
Gender & Women & 84 \\
& Men & 52 \\
Duration of residence & Less than one & 13 \\
& Between 1 and 5 & 28 \\
& Between 6 and 15 & 33 \\
& Between 16 and 30 & 27 \\
& More than 30 & 33 \\
Can you name this plant & No answer & 2 \\
(when not flowering)? & Yes & 7 \\
Can you name this plant & No & 129 \\
(when flowering)? & Yes & 6 \\
Have you ever seen this & No & 130 \\
plant around here & Yes & 99 \\
(when not flowering)? & No & 26 \\
Have you ever seen this & Maybe & 11 \\
plant around here & Yes & 91 \\
(when flowering)? & No & 41 \\
\hline & Maybe & 4 \\
\hline & & \\
& &
\end{tabular}

presented a flowering or a nonflowering plant. Nevertheless, most surveyed people stated that they had already seen this plant around their living area (73\% and $67 \%$ when presented with a nonflowering and a flowering plant, respectively).

Regarding the esthetic assessments of the landscapes, the knowledge (i.e., the ability to recognize and name the plant) of the surveyed people, as well as the presence/height of Fallopia, significantly influenced the esthetic ratings given by the participants for the landscapes (Fig. 2). The people who recognized and were able to name Fallopia assigned lower ratings $($ mean $=5.8)$ than the people who did not $($ mean $=6.8)$ (ANOVA; $F=9321 ; \mathrm{df}=2 ; p<0.0001$ ). The people who recognized and named Fallopia were older than people who did not (five out of eight were older than 60 years) and had a high level of education ( 3 years or more of graduate studies for half of them). Most of them regularly or frequently visit the banks of the Rhône River, mostly for walks. The height of Fallopia in the landscape also significantly influenced the esthetic ratings (ANOVA; $F=10.5 ; \mathrm{df}=2 ; p<0.0001$ ). The scenes with high amounts of Fallopia received the lowest ratings (mean $=6.4$ ); the scenes with low Fallopia received intermediate ratings (mean $=6.8$ ), whereas the scenes without Fallopia received the highest ratings (mean $=7$ ). The interaction between knowledge and the presence/height of Fallopia was not significant (ANOVA; $F=2.2 ; \mathrm{df}=2 ; p=0.1$ ). Nevertheless, the pairwise comparisons showed that people who were able to recognize and name Fallopia had a different perception of scenes with high Fallopia (Tukey's test; $p<0.001$ ). They assigned significantly lower ratings to landscapes with high Fallopia $($ mean $=5)$ than the people who were not able to identify the species $($ mean $=6.1)$.

\section{Social representations of Fallopia spp. in managers and users}

Overall, the potential central core is composed of four elements (Table 2): the highly "invasive" characteristics of Fallopia, its "density," its contribution to the "degradation" of the environment, and the fact that it is a "plague" or a serious threat. The general tone of the free associations was mostly negative in the central core where all potentially central elements refer to aversive aspects. Moreover, the first periphery (high frequency and low rank) contains the idea that Fallopia is "unmanageable." The other peripheral elements are more mixed, with positive terms such as "beauty," "flowers," or "nature." The term "foreign" is also relatively frequent and important in the periphery.

We observed in the CFA analysis (Fig. 3) that the four elements previously determined as central ("invasive," "density," "plague," and "degradation") do not contribute in any way to the inertia of either factor. Hence, all stakeholders share the same elements in each location. In other terms, these elements are truly the structural basis of the shared representation of Fallopia. Moreover, the apparent contradiction between positive and negative terms in the periphery is explained because the global and transversal social representation is significantly nuanced depending on the area and the social stakeholder's group (managers and users). The first axis of the CFA analysis (Fig. 3) revealed a contrast between the Rhône and the Gard areas. The former perceives Fallopia as "unmanageable," whereas the latter rather considers Fallopia a "foreign" plant. On the second axis, a different representation of the species between managers and users can be observed. In addition to the common elements of the central core, users mentioned the "beauty" of Fallopia's "flowers," the fact that it provides "greenery," and the fact that it constitutes a "natural" aspect of the environment. Thus, they are in opposition to the managers who see Fallopia as present in the "river banks" and who referred to the ongoing "struggle" to limit its proliferation.

\section{Discussion}

The management of ecosystems is more efficient when ecological and social factors are considered (Austin et al. 2013). There 


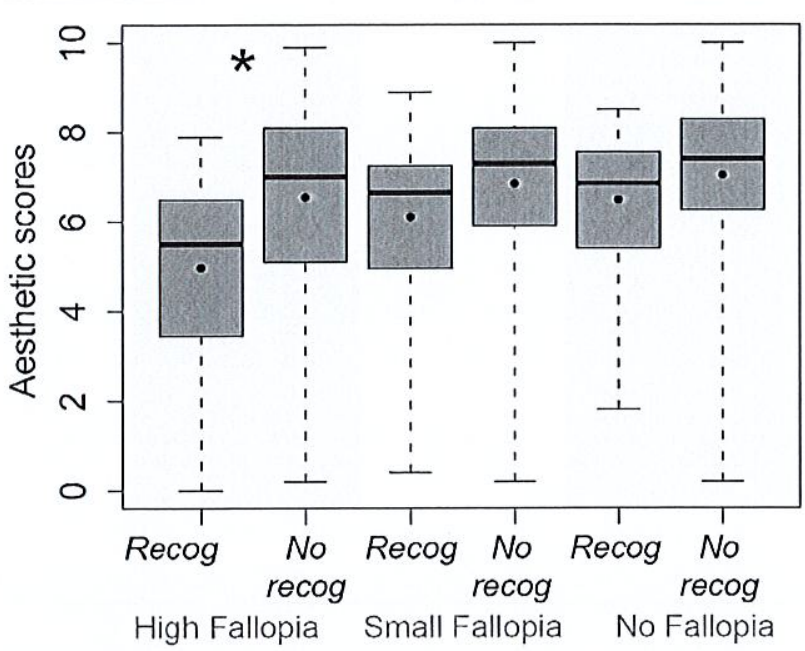

Fig. 2 Distribution of the esthetic ratings assigned to the scenes according to the presence and height of Fallopia and to the ability of the people to name the plant. "Recog"/"No recog": sample of the population that was/ was not able $(n=8 / n=128)$ to recognize and name the plant (regardless of whether the plant was recognized with or without flowers). Points in the boxes indicate the mean of ratings. Whiskers represent upper and lower quartiles, and the star indicates the significance of the differences between "Recog" and "No recog" (Tukey's test, $p<0.001$ )

is need for precise ecological and socioeconomic management motivations and objectives, and the motivations and objectives should be linked to optimal management techniques. Here, we used two different approaches - the study of the esthetic perceptions of laypeople and analysis of the representations of Fallopia spp. of users and managers of invaded sites-to nourish a discussion about management motivations and objectives in the context of Fallopia's invasion in France.

\section{Landscapes with tall plants are less esthetically appreciated, especially if the species is recognized}

According to our results on the public perception of landscape esthetics, the sole presence of Fallopia in landscapes only marginally decreased the esthetic value. The height of the plant was, however, shown to have a slight but significant impact on the evaluations. The more the plant was visible in the landscape, the less the landscape was perceived as esthetically appealing. Those results may be surprising because Fallopia spp. was sold in the nineteenth century as ornamental species (Bailey and Conolly 2000). Here, the demonstrated effect is weak and may have been stronger if the set of photographs had included more widely invaded landscapes (e.g., colonized by dense and monospecific massifs of Fallopia spp.). Here, the set of photographs included riparian landscapes, with Fallopia as a part of this landscape among other species, and not as a central object. This low footprint in the landscape was, however, enough to induce an impact on perceptions and the esthetic value associated with landscapes. The presence of Fallopia spp. in the landscape thus appears
Table 2 Structure and content of the social representation of Fallopia spp. (managers and users combined). The participants in the questionnaire survey were asked to cite the first 5 words that they associated with Fallopia and to rank these words from 1 (the most characteristic of Fallopia) to 5 (the least characteristic). The frequencies among all the participants of each semantic element cited and their mean assigned ranks are in brackets. The elements with a higher frequency of positive answers to the context independence test (CIT) compared to Kolmogorov-Smirnov's threshold are in bold. The central elements are the elements with high rank and high frequency

\begin{tabular}{|c|c|c|}
\hline & $\begin{array}{l}\text { Considered as } \\
\text { characteristic } \\
(\text { high rank <3.00) }\end{array}$ & $\begin{array}{l}\text { Considered as less } \\
\text { characteristic } \\
\text { (low rank } \geq 3.00 \text { ) }\end{array}$ \\
\hline $\begin{array}{l}\text { High frequency } \\
\qquad(>20)\end{array}$ & $\begin{array}{l}\text { Invasive }(90 ; 1.92) \\
\text { Density }(34 ; 2.94) \\
\text { Degradation }(21 ; 2.57) \\
\text { Plague }(21 ; 2.76)\end{array}$ & $\begin{array}{l}\text { Water }(29 ; 3.20) \\
\text { Unmanageable }(25 ; 3.08)\end{array}$ \\
\hline $\begin{array}{l}\text { Low frequency } \\
\qquad(\leq 20)\end{array}$ & $\begin{array}{l}\text { Flowers }(17 ; 2.53) \\
\text { Plant }(12 ; 2.45) \\
\text { Nature }(8 ; 2.87)\end{array}$ & $\begin{array}{l}\text { Foreign }(19 ; 3.00) \\
\text { Beauty }(15 ; 3.13) \\
\text { Struggle }(9 ; 3.22) \\
\text { Greenery }(9 ; 3.44) \\
\text { River banks }(9 ; 3.88)\end{array}$ \\
\hline
\end{tabular}

to raise esthetic issues according to the public. Since it is known that the esthetically perceived environments are those that induce a stronger commitment to environmental preservation (Nassauer 1992; Gobster et al. 2007), esthetic issues should be considered more widely when defining management strategies towards Fallopia spp.

In our survey, the people who knew the species (who were able to recognize and name it) had a far more negative perception of the landscapes containing high levels of Fallopia. Knowledge plays a determinant role in the perception of Fallopia (Robinson et al. 2017), as has already been demonstrated for other invasive species (García-Llorente et al. 2008). These results demonstrated how important communication plans are for invasive species. For example, the number of visitors expressing a willingness to pay for controlling pine invasion in the Malalcahuello National Reserve in Chile increased after a brief explanation about the impacts of the pines (Bravo-Vargas et al. 2018). Due to its strong potential impacts, the message that is conveyed to the public must be discussed in depth and jointly defined by all stakeholders. Indeed, Novoa et al. (2018) recommend the co-design of management objectives, time frames, and the management strategy after an assessment of the perceptions and beliefs of "key" stakeholders.

\section{Diversity of social representations of Fallopia between groups of stakeholders}

The influence of knowledge and experience is also tangible in our social representation study; we demonstrated a contrast between people who know Fallopia because they must address the species in their work, i.e., managers, and other people (users). The users highlighted the green and natural aspects 


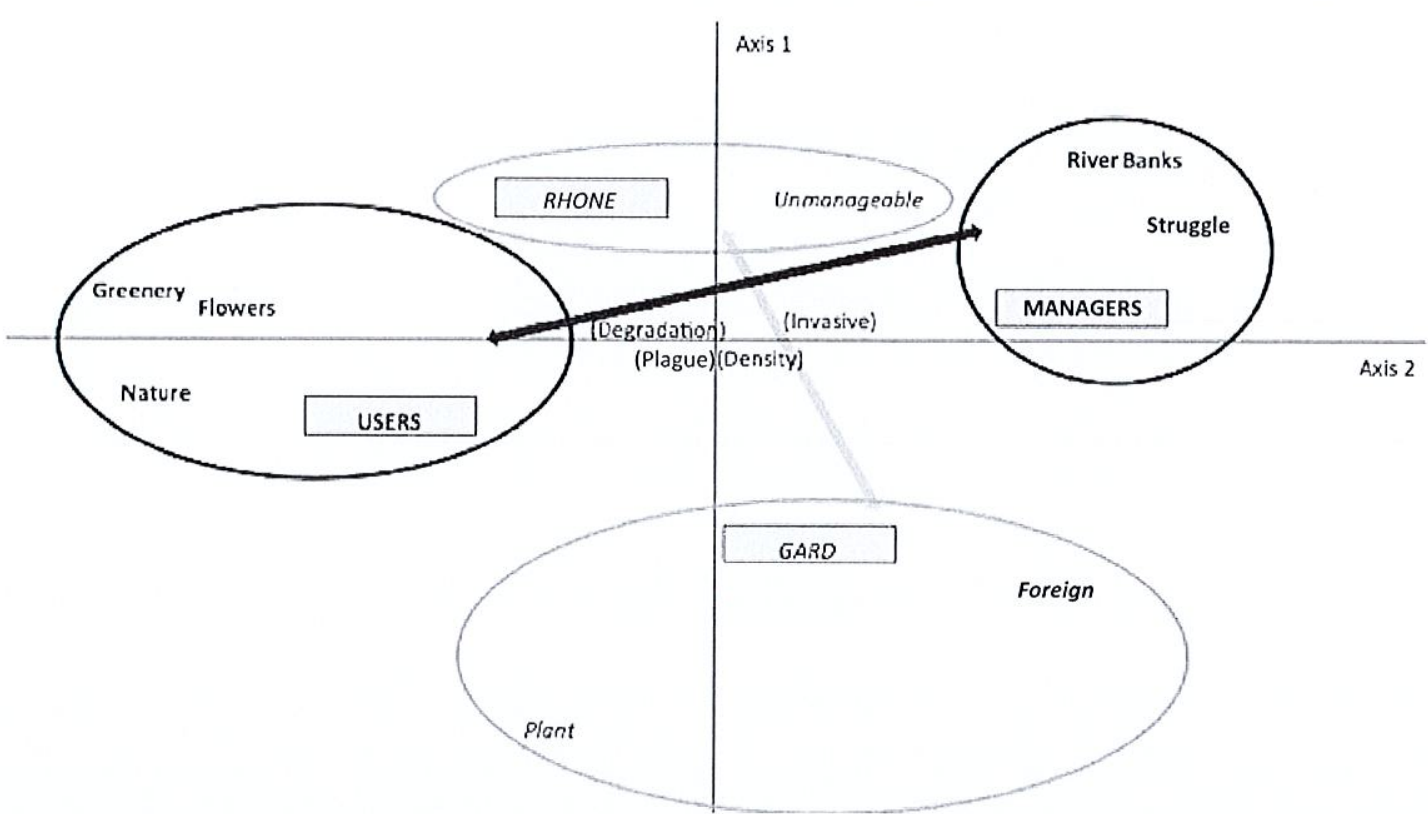

Fig. 3 Factorial plan (axes 1 and 2) of the correspondence factorial analysis (CFA) built on the occurrence of the 14 semantic elements (resulting from the content analysis led by the words cited by participants)

of the species and saw the species as a plant and not only as an invasive species. The managers focused on aspects linked to their work: the impact of the plant on watercourses and the difficulty of controlling the invasion. Likewise, managers in a highly invaded area considered the species to be unmanageable, whereas managers from a more recently invaded area underlined the exotic origin of the plant by talking about a "foreign" species. All these results confirmed the importance of knowledge in the social representations. Nevertheless, the central core shared by all groups of respondents was globally negative. The motivation of managers to take action against invasive species could be driven by management goals but could also be influenced by their representations and knowledge because biological invasions are both a biological and a cultural phenomenon (Tassin and Kull 2015). Here, the notion of impacts arose in the central core of representations ("degradation," "plague") and may be one of the main motivations for management actions. The word "foreign" appeared in the periphery, especially in the Gard area. We lack data to determine if the non-nativeness of the species may be one motivation to engage management actions in this area. Further investigations on the role of the status of a species (native versus non-native) in the motivation for taking action would be interesting because this is a controversial issue that calls upon different worldviews (Simberloff 2012).

\section{Including social factors in the design of management plans}

The objectives of the plan must be stated clearly when a management plan is considered. Larson et al. (2011) applied the concept of "sustainability" to invasive species management and suggested that specific management goals be formulated in three "pillars": environmental, social and economic, and be measurable, meaningful, and understandable to all stakeholders. The social pillars imply the involvement of all stakeholders and build the communication between stakeholders and managers (Larson et al. 2011). An information program about Fallopia (including if broader ecological principles are needed, Caplat and Coutts 2011) and the behaviors that could limit its spread should be considered given the small number of people who recognized the species in the pool of respondents. Moreover, a better understanding of how the involved populations perceive Fallopia can facilitate the development and implementation of communication strategies to advocate best practices according to the target audience. Furthermore, actions to take towards Fallopia can be jointly defined by discussions involving several stakeholders showing different representations of the species.

Our study thus highlights the role of human perceptions and representations in invasive species management, both at the individual and the social levels. It is now recommended to assess stakeholders' beliefs before designing management plans, especially when dealing with potential "conflict species" (Novoa et al. 2018). For example, in a worldwide study, Kull et al. (2011) analyzed uses and perception of Australian acacias and found that although negative impacts are underlined in rich countries, a control of these species would likely impact poor communities that depend on the use of Acacias. Furthermore, such studies may show that even if uses and representations of species differ between stakeholders, there may be surprisingly fewer conflicts about the management of the species than previously expected. In 
South Africa, even if perceptions of Prosopis sp. varied among stakeholders from different social contexts and with diverse familiarity with the species, Shackleton et al. (2015) identified a demand for improved and increased control of the species linked to a general view that Prosopis sp. are spreading and costly. Actually, Shackleton et al. (2018) identified around 30 interacting and dynamic factors (including species-, effects-, sociocultural, and landscape-related factors) that could influence people's perceptions/representations of invasive species, in six broad-scale dimensions from individuals to institutional context. This synthesis underlines the potential complexity of human perceptions and representations and helps understanding their potential role in ecosystem management.

To conclude, the results of the present study highlighted that the perceptions of laypeople of landscape esthetics are influenced slightly by the height of the species unless the species is recognized, in which case its presence is evaluated more negatively. Social representations, which are mainly negative, are different among stakeholders and study areas. Altogether, these results may help design socially adequate management plans, with positive feedback between society and the environment (Larson et al. 2011). The next step would be to combine and integrate ecological and social factors in one study. Such projects are needed to link the social and ecological aspects of biological invasions, which is crucial for understanding management (or the absence of management) motivations, formulating realistic and efficient management objectives, and building better management plans.

Acknowledgements The authors would like to thank J. Valy for the survey on landscape perception, E. Wiederkehr and L. Vaudor for their help in data processing and statistical analysis of the photoquestionnaire data, D. Lassarre for her involvement at the beginning of the project, and A. Chesterman for his proofreading.

Funding information This research was financially supported by the regional water agency (in partnership with the LTER-ZABR) and the IngECOTech program (INEE-CNRS).

\section{References}

Abric JC (1976) Jeux, conflits et représentations sociales. Thèse de doctorat d'Etat (PhD thesis), Aix-en-Provence, Université de Provence

Abric JC (1994a) Pratiques sociales et représentations. PUF, Paris

Abric JC (1994b) L'organisation interne des représentations sociales : système central et système périphérique. In: Guimelli C (ed) Structure et transformation des représentations sociales. Delachaux et Niestlé, Lausanne

Abric JC (2003) La recherche du noyau central et de la zone muette des représentations sociales. Erès/Hors collection:59-80

Andreu J, Vila M, Hulme PE (2009) An assessment of stakeholder perceptions and management of noxious alien plants in Spain. Environ Manag 43:1244-1255
Austin Z, Raffaelli DG, White PCL (2013) Interactions between ecological and social drivers in determining and managing biodiversity impacts of deer. Biol Conserv 158:214-222

Bailey JP, Conolly AP (2000) Prize-winners to pariahs - a history of Japanese Knotweed s.l. (Polygonaceae) in the British Isles. Watsonia 23:93-110

Bailey J, Wisskirchen R (2004) The distribution and origins of Fallopia x bohemica (Polygonaceae) in Europe. Nord J Bot 24:173-199

Bailey JP, Bímová K, Mandák B (2009) Asexual spread versus sexual reproduction and evolution in Japanese Knotweed s.l. sets the stage for the "Battle of the Clones". Biol Invasions 11:1189-1203

Bravo-Vargas V, García RA, Pizarro JC, Pauchard A (2018) Do people care about pine invasions? Visitor perceptions and willingness to pay for pine control in a protected area. J Environ Manage. https:// doi.org/10.1016/j.jenvman.2018.07.018

Buijs AE, Elands BHM (2013) Does expertise matter? An in-depth understanding of people's structure of thoughts on nature and its management implications. Biol Conserv 168:184-191

Buijs A, Hovardas T, Figari H, Castro P, Devine-Wright P, Fischer A, Mouro C, Selge S (2012) Understanding people's ideas on natural resource management: research on social representations of nature. Soc Natur Resour 25:1167-1181

Caplat P, Coutts SR (2011) Integrating ecological knowledge, public perception and urgency of action into invasive species management. Environ Manag 48:878-881

Catford JA, Jansson R, Nilsson C (2009) Reducing redundancy in invasion ecology by integrating hypotheses into a single theoretical framework. Divers Distrib 15:22-40

Cottet M, Piégay H, Bornette G (2013) Does human perception of wetland aesthetics and healthiness relate to ecological functioning? J Environ Manag 128:1012-1022

Cottet M, Piola F, Le Lay YF, Rouifed S, Rivière-Honegger A (2015) How environmental managers perceive and approach the issue of invasive species: the case of Japanese knotweed s.l. (Rhône River, France). Biol Invasions 17:3433-3453

Delbart E, Mahy G, Weickmans B, Henriet F, Cremer S, Pieret N, Vanderhoeven S, Monty A (2012) Can land managers control Japanese knotweed? Lessons from control tests in Belgium. Environ Manag 50:1089-1097

Epanchin-Niell RS, Hastings A (2010) Controlling established invaders: integrating economics and spread dynamics to determine optimal management. Ecol Lett 13:528-541

Estévez RA, Anderson CB, Pizarro JC, Burgman MA (2015) Clarifying values, risk perceptions, and attitudes to resolve or avoid social conflicts in invasive species management. Conserv Biol 29:19-30

Figari H, Skogen K (2011) Social representations of the wolf. Acta Sociol 54:317-332

Fischer A, Selge S, van der Wal R, Larson BMH (2014) The public and professionals reason similarly about the management of non-native invasive species: a quantitative investigation of the relationship between beliefs and attitudes. PLoS One 9:e105495

Flament C (1989) Structure et dynamique des représentations sociales. In: Jodelet D (ed) Les représentations sociales. PUF, Paris

Flament C (1999) La représentation sociale comme système normatif. Psychologie Société 1:29-54

Gaertner M, Novoa A, Fried J, Richardson DM (2017) Managing invasive species in cities: a decision support framework applied to Cape Town. Biol Invasions 19:3707-3723

García-Llorente M, Martín-López B, González JA, Alcorlo P, Montes C (2008) Social perceptions of the impacts and benefits of invasive alien species: implications for management. Biol Conserv 141: 2969-2983

Giljohann KM, Hauser CE, Williams NSG, Moore JL (2011) Optimizing invasive species control across space: willow invasion management in the Australian Alps. J Appl Ecol 48:1286-1294 
Gobster PH, Nassauer JI, Daniel TC, Fry G (2007) The shared landscape: what does aesthetics have to do with ecology? Landsc Ecol 22:959972

Guimelli C (1994) Structure et transformation des représentations sociales. Delachaux et Niestlé, Lausanne

Hohmann MG, Just MG, Frank PJ, Wall WA, Gray JB (2013) Prioritizing invasive plant management with multi-criteria decision analysis. Invas Plant Sci Mana 6:339-351

Kull CA, Shackleton CM, Cunningham PJ, Ducatillon C, Dufour-Dror JM, Esler KJ, Friday JB, Gouveia AC, Griffin AR, Marchante E, Midgley SJ, Pauchard A, Rangan H, Richardson DM, Rinaudo T, Tassin J, Urgenson LS, von Maltitz GP, Zenni RD, Zylstra MJ (2011) Adoption, use and perception of Australian acacias around the world. Divers Distrib 17:822-836

Larson DL, Phillips-Mao L, Quiram G, Sharpe L, Stark R, Sugita S, Weiler A (2011) A framework for sustainable invasive species management: environmental, social, and economic objectives. J Environ Manag 92:14-22

Le Lay YF, Piégay H, Gregory K, Chin A, Dolédec S, Elosegi A, Mutz M, Wyzga B, Zawiejska J (2008) Variations in cross-cultural perception of riverscapes in relation to in-channel wood. T I Brit Geogr 33:268-287

Le Lay YF, Cottet M, Piégay H, Rivière-Honegger A (2012) Ground imagery and environmental perception: using photo-questionnaires to evaluate river management strategies. In: Carbonneau PE, Piégay $\mathrm{H}$ (eds) Fluvial remote sensing for science and management. Pages 405-29

Liu JG, Linderman M, Ouyang ZY, An L, Yang J, Zhang HM (2001) Ecological degradation in protected areas: the case of Wolong Nature Reserve for giant pandas. Science 292:98-101

Liu J, Dietz T, Carpenter S et al (2007) Complexity of coupled human and natural systems. Science 317:1513-1516

Lo Monaco G, Lheureux F, Halimi-Falkowicz S (2008) Test of context independence (TCI) and structure of social representations. Swiss J Psychol 67:119-123

Meier ES, Dullinger S, Zimmermann NE, Baumgartner D, Gattringer A, Huelber K (2014) Space matters when defining effective management for invasive plants. Divers Distrib 20:1029-1043

Moliner P, Rateau P, Cohen-Scali V (2002) Les représentations sociales. Pratiques des études de terrain. Presses Universitaires de Rennes, Rennes

Moscovici S (1961) La psychanalyse, son image et son public. PUF, Paris

Moscovici S (1989) Préface. In: Jodelet D (ed) Folie et représentations sociales. PUF, Paris

Nassauer JI (1992) The appearance of ecological systems as a matter of policy. Landsc Ecol 6:239-250

Novoa A, Shackleton R, Canavan S, Cybèle C, Davies SJ, DehnenSchmutz K, Fried J, Gaertner M, Geerts S, Griffiths CL, Kaplan H, Kumschick S, le Maitre DC, Measey GJ, Nunes AL, Richardson DM, Robinson TB, Touza J, Wilson JRU (2018) A framework for engaging stakeholders on the management of alien species. J Environ Manag 205:286-297

Ostrom E (2009) A general framework for analyzing sustainability of social-ecological systems. Science 325:419-422

Parepa M, Fischer M, Krebs C, Bossdorf O (2014) Hybridization increases invasive knotweed success. Evol Appl 7:413-420

R Core Team (2012) R: a language and environment for statistical computing. R Foundation for Statistical Computing, Vienna, Austria. ISBN 3-900051-07-0
Rateau P (1999) Les représentations sociales. In: Pétard JP (ed) Psychologie sociale. Bréal, Paris

Rateau P (2002) Procédure de substitution et nature des éléments des représentations sociales. Les Cahiers Internationaux de Psychologie Sociale 54:62-70

Real E, Arce C, Sabucedo JM (2000) Classification of landscapes using quantitative and categorical data, and prediction of their scenic beauty in north-western Spain. J Environ Psychol 20:355-373

Redman CL, Grove JM, Kuby LH (2004) Integrating social science into the long-term ecological research (LTER) network: social dimensions of ecological change and ecological dimensions of social change. Ecosystems 7:161-171

Robinson BS, Inger R, Gaston KJ (2017) Drivers of risk perceptions about the invasive non-native plant Japanese knotweed in domestic gardens. Biol Invasions 19:2927-2940

Rouquette ML, Rateau P (1998) Introduction à l'étude des représentations sociales. Presses Universitaires de Grenoble, Grenoble

Selge S, Fischer A (2011) How people familiarize themselves with complex ecological concepts-anchoring of social representations of invasive non-native species. J Appl Soc Psychol 21:297-311

Shackleton RT, Le Maitre DC, Richardson DM (2015) Stakeholder perceptions and practices regarding Prosopis (mesquite) invasions and management in South Africa. Ambio 44:569-558

Shackleton RT, Richardson DM, Shackleton CM, Bennett B, Crowley SL, Dehnen-Schmutz K, Estévez RA, Fischer A, Kueffer C, Kull CA, Marchante E, Novoa A, Potgieter LJ, Vaas J, Vaz AS, Larson BMH (2018) Explaining people's perceptions of invasive alien species: a conceptual framework. J Environ Manag. https://doi.org/10. 1016/j.jenvman.2018.04.045

Simberloff D (2012) Nature, natives, nativism, and management: worldviews underlying controversies in invasion biology. Environ Ethics 34:5-25

Simberloff D, Martin JL, Genovesi P, Maris V, Wardle DA, Aronson J, Courchamp F, Galil B, García-Berthou E, Pascal M, Pyšek P, Sousa R, Tabacchi E, Vilà M (2013) Impacts of biological invasions: what's what and the way forward. Trends Ecol Evol 28:58-66

Tassin J, Kull CA (2015) Facing the broader dimensions of biological invasions. Land Use Policy 42:165-169

Turner BL, Geoghegan J, Lawrence D et al (2016) Land system science and the social-environmental system: the case of Southern Yucatan Peninsular Region (SYPR) project. Curr Opin Environ Sustain 19: 18-29

Vaz AS, Kueffer C, Kull CA, Richardson DM, Schindler S, MuñozPajares AJ, Vicente JR, Martins J, Hui C, Kühn I, Honrado JP (2017) The progress of interdisciplinarity in invasion science. Ambio 46:428-442

Vergès P (1992) L'évocation de l'argent : une méthode pour la définition du noyau central d'une représentation. Bulletin de psychologie, XLV

Wyzga B, Zawiejska J, Le Lay YF (2009) Influence of academic education on the perception of wood in watercourses. J Environ Manag 90:587-603

Zouhri B, Feliot-Rippeault M, Michel-Guillou E, Weiss K (2016) Representations of pesticides and social practices: the case of French farmers. Environ Sci Pollut R 23:157-166 